\title{
Rethinking the Health Care Model through the reorientation of training
}

\author{
Repensando o modelo de Atenção em Saúde mediante a reorientação da formação \\ Repensando el modelo de Atención en Salud mediante la reorientación de la formación
}

\section{Carine Vendruscolo', Letícia De Lima Trindade', Marta Lenise do Prado", Maria Elisabeth Kleba"II}

'Universidade do Estado de Santa Catarina. Chapecó, Santa Catarina, Brazil.

"Universidade Federal de Santa Catarina. Florianópolis, Santa Catarina, Brazil.

"' Universidade Comunitária da Região de Chapecó. Chapecó, Santa Catarina, Brazil.

\begin{abstract}
How to cite this article:
Vendruscolo C, Trindade LL, Prado ML, Kleba ME. Rethinking the Health Care Model through the reorientation of training. Rev Bras Enferm [Internet]. 2018;71(Suppl 4):1580-8. [Thematic issue:

Education and Teaching] DOI: http://dx.doi.org/10.1590/0034-7167-2017-0055
\end{abstract}

Submission: 03-06-2017 Approval: 12-22-2017

\section{ABSTRACT}

Objective: to understand the contributions of the National Program of Reorientation of Professional Training in Health (PróSaúde) for the change in the model of care and training of health professionals. Methods: a case study with representatives of the teaching, care, management and social control, participants of the management units of the Pró-Saúde (Charitable institution for social and hospital assistance), in a municipality of the south of Brazil. Data collection took place through interviews and observations between October 2012 and February 2013. Results: the Program acts as a device for the transition of health care and training models, by promoting the problematization of daily work and the approximation between teaching and service. Emphasis is placed on the importance of the subjects' commitment and the different perspectives on the community. Conclusion: Pró-Saúde leaves visible marks in the process of qualifying students and professionals, as well as promoting collaborative action in the fields of management, care, teaching and social control in the SUS (Brazilian Unified Health System).

Descriptors: Training in Human Resources; Services of Teaching-Assistance Integration; Health Management; Primary Health Care; Health Policy.

\section{RESUMO}

Objetivo: compreender as contribuições do Programa Nacional de Reorientação da Formação Profissional em Saúde (Pró-Saúde) para a mudança no modelo de atenção e de formação de profissionais de saúde. Métodos: estudo de caso com representantes do ensino, atenção, gestão e controle social, participantes das instâncias gestoras do Pró-Saúde, em um município do sul do Brasil. A coleta de dados ocorreu mediante entrevistas e observações, entre outubro de 2012 e fevereiro de 2013. Resultados: o Programa atua como dispositivo para a transição de modelos de atenção e formação em saúde, ao promover a problematização do cotidiano do trabalho e a aproximação entre ensino e serviço. Salienta-se a importância do comprometimento dos sujeitos e dos diferentes olhares sobre a comunidade. Conclusão: o Pró-Saúde deixa marcas visíveis no processo de qualificação de estudantes e profissionais, além de promover a atuação colaborativa nos campos da gestão, atenção, ensino e controle social no SUS.

Descritores: Formação de Recursos Humanos; Serviços de Integração Docente-Assistencial; Gestão em Saúde; Atenção Primária em Saúde; Política de Saúde.

\section{RESUMEN}

Objetivo: comprender las contribuciones del Programa Nacional de Reorientación de la Formación Profesional en Salud (Pró-Saúde) para el cambio en el modelo de atención y de formación de profesionales de salud. Métodos: estudio de caso con representantes de la enseñanza, atención, gestión y control social, participantes de las instancias gestoras del Pró-Saúde, en un municipio del sur de Brasil. La recolección de datos ocurrió mediante entrevistas y observaciones, entre octubre de 2012 y febrero de 2013. Resultados: el Programa actúa como dispositivo para la transición de modelos de atención y formación en salud, al promover la problematización del cotidiano del trabajo y la aproximación entre enseñanza y servicio. Se destaca la importancia del compromiso de los sujetos y de las diferentes 
miradas sobre la comunidad. Conclusión: el Pró-Saúde deja marcas visibles en el proceso de calificación de estudiantes y profesionales, además de promover la actuación colaborativa en los campos de la gestión, atención, enseñanza y control social en el SUS.

Descriptores: Formación de Recursos Humanos; Servicios de integración Docente-Asistencial; Gestión de la Salud; Atención Primaria en Salud; Política de Salud.

\section{CORRESPONDING AUTHOR Carine Vendruscolo E-mail: carine.vendruscolo@udesc.br}

\section{INTRODUCTION}

Health management involves coping with the conflicts generated in the fields of politics and work, bases of the organizations in which the evolution of care models operates on a daily basis ${ }^{(1)}$. The transformations of such models, from the technological incorporation and the adversities of the subjects that produce care, make questioning the granted accreditation for the professional exercise by Higher Education Institutions (HEI) that operate in this area. In this context, in Brazil, the approximation between the Ministries of Health (MS) and Education (MEC) has resulted in actions that articulate policies to promote the training of workers prepared for resolutive and higher quality health care.

In the scope of training and development of people to work in the Brazilian Unified Health System (SUS), the Ministries articulate initiatives aimed at changes in undergraduate education and the workers included in the System. Among other actions related to training, the MS implemented the National Program for Reorientation of Vocational Healthcare Training (Pró-Saúde), with the aim of provoking changes in the process of knowledge generation and service delivery to the population ${ }^{(3-5)}$. Based on SUS guidelines and interministerial ordinance for reorientation of health education, learning should be based on the questioning - a transformative and emancipatory pedagogical conception inspired by Paulo Freire ${ }^{(6)}$ adopted as a theoretical reference for this study - based on the needs of qualification of the practices and relationships developed in the spaces where health care occurs. It is considered that the pedagogical relationship between the subjects involved in learning is based on dialogue, which is satisfactory for them and also for the people who are benefited by the care ${ }^{(7)}$. Thus, student and professor are subjects of practice, created and recreated through action-reflection-action on everyday life. Based on the interaction with reality, intervention actions - in this case, in the health area - provoke transformation; and it is through the development of the ability to "learning by doing" that this interaction is consolidated ${ }^{(6,8)}$. However, the training process does not always meet the demands of the real health practice settings, because of its distance from reality, which causes a problem ${ }^{(9)}$ together with the distance between teaching and care institutions.

The integrated proposal of Pró-Saúde, jointly with the Universidade Comunitária da Região de Chapecó (Unochapecó), Municipal Secretary of Health and Regional Health Management of Chapecó, municipality located in the State of Santa Catarina (SC), southern Brazil, aims to consolidate the commitment to promote changes in professional training and, therefore, in the Permanent Education movements of professionals, with a focus on the loco-regional reality. The strategy of reorientation of training is accompanied by a Local Steering Committee (LSC) and a General Coordinating Committee (GCC), instances of dialogue between representatives of the two structures, with a view to monitoring and improving the proposal.

Studies ${ }^{(10-11)}$ demonstrate the contribution of the Pró-Saúde Program in the initiatives of curricular changes, through the greater participation of students in the process of knowledge construction and the creation of learning spaces, involving workers, professors and students in the production of services. They converge to understand the teaching-service articulation as a possibility to consolidate the program and contribute to the SUS. This perspective intensifies when guided by strategies of shared management of the reorientation initiatives carried out in the co-responsibility of the segments involved - management, teaching, care and social control, resulting in the democratization of the process. It is considered that the effective interaction between the segments that form part of the training produces a greater commitment on the part of the actors involved, by means of bonding and accountability between managers of the teaching and service institutions, professors, students, users and professionals of the network of care, as well as other partners in the production of teaching and health care ${ }^{(12)}$.

Considering this setting and assumptions, it is questioned: How the political strategies of reorientation of the training in health have been contributing with the processes of change in the care and training model?

\section{OBJECTIVE}

To understand the contributions of the Pró-Saúde Program for the change in the model of care and training of health professionals.

\section{METHOD}

\section{Ethical aspects}

The study was approved by the Human Research Ethics Committee of the Universidade Federal de Santa Catarina (UFSC), in compliance with the criteria of the National Health Council (Conselho Nacional de Saúde) Resolution 466/12. After presenting the study objectives to the participants, the Informed Consent Form was obtained. In order to preserve anonymity, the participants were identified by the names of classic characters from the Brazilian literature and the letter corresponding to the represented segment (management - M, care - $\mathrm{C}$, social control - SC and T - teaching).

\section{Type of study}

This is a case study ${ }^{(13)}$, developed in two management bodies (LSC and GCC) that are articulated from the Pró-Saúde proposal in Chapecó/SC. 


\section{Setting and participants of the study}

Representatives of the management (representatives of the health department), care (care network professionals), teaching (HEI professors and students) segments and representatives of social control (community members and/or their representatives) participated in the study, which make up the "quadrilateral of SUS formation"(14) within the LSC and the GCC.

The purpose of the LSC is to follow the program execution process and be a channel for dialogue with its representatives, presenting suggestions for improving the proposal. The purpose of GCC is to conduct mediation and articulation in dialogue with peers, guiding project authors and others involved and motivating them to engage the proposal. As inclusion criteria for interviews, participants should have integrated one of the bodies related to the management of the Pró-Saúde Project, as representatives of one of the four segments, from 2006 to 2012 (validity of the proposal). Those who were retired or retired (medical leave, among others) during the period were excluded. Thus, out of a total of 25 eligible members, 11 were interviewed, with five members of the LSC, three members of the GCC and three members of both bodies. The majority were women (eight) from different training areas: Nursing, Social Work, Physical Education, Physiotherapy, Psychology, Dentistry and Administration.

\section{Collection and organization of data}

The data were collected through interviews and participant observation of the meetings of the two bodies between October 2012 and February 2013. The interview followed a semi-structured script containing the information: teaching-service integration, institutions involved, history the participation of the actors, representation of the segments, among others. The observation of the meetings of the Steering Committee and the Coordinating Committee were carried out in six moments and 25 members took part, with an average duration of four hours. For the observation, a pre-elaborated script was used containing the following items: organization, planning and dynamics of the meetings; the dialogues, participation and conflicts. The observations were recorded in the field diary.

\section{Data analysis}

The data were analyzed from the operational proposal for the analysis of qualitative data ${ }^{(15)}$. Firstly, the raw material was pre-analyzed by means of the floating reading of the transcripts of the statements and of the records in the field diary, in order to constitute the corpus of the information. We then set out for the exploratory phase that resulted in the first coding in order to reach the core of understanding the text. Finally, the text was cut into registration units. Paulo Freire's ideas were used as theoretical reference, resulting in four categories: Pró-Saúde: pedagogical articulation between courses and change of care model; Pró-Saúde as a mobilizer of the territory of practice: commitment of the subjects; Pró-Saúde: the reality as living bibliographical material; and Pró-Saúde: different looks and places in the training process.

\section{RESULTS}

Pró-Saúde: pedagogical articulation between courses and change of care model

Pró-Saúde contributes to social transformation, since it brings the world of teaching and work closer together, encouraging change. Although the members of the management bodies of the proposal do not have tools to measure their impact, they indicate that there is an expectation of the service, especially of the employees, in relation to the immediate results of the actions:

[...] I could not, at any moment, measure how much it brings positive or negative impacts for the service. But, I realize that every project that is being developed [...] has an innovative proposal, with an expectation of a quick result. The workers think that, from this project, something will change. (Bibiana - M)

Despite the efforts of these and other interministerial initiatives aimed at reorienting the training and practices of Health Care, there is a difficulty in transforming the current model. This happens because there is a movement of deconstruction, related to what, theoretically, is considered ideal and what is possible when acting in and on reality, that is, the differences between the prescribed and the real enter into the picture. The reorientation that Pró-Saúde proposes would be tied to what is feasible to the professional and what the university wants, besides the need to consider what the user, as beneficiary of the service, demands. It also implies the change of individual behaviors:

I perceive a movement of deconstruction ... the practice is very different from theory, because while we theorize and think about the change in a model, the difficulty of transforming this model is very great because it is operational [...] enter the differences, of the educational institution that wants a model and what it is possible to do, that the management allows; and what the worker can, at that moment, to the detriment of the greater requirement that is the user. (Bibiana - M)

[...] as professionals we have to work, and change behaviors, you imagine in a community, that has $X$ heads, cultures, works with age group, older people already have their beliefs, and it is very difficult. (Alice - SC)

For the representatives of management, the transformations of the models are visible in the scope of training and work, but the conceptions of the user are still focused on the hegemonic model of care, centered on the physician and the cure of diseases. This change in the field of practices seems to be a slow movement, that is, it does not advance in the same rhythm as the proposals that guide the "SUS model". The need to better prepare the care individuals who still resist the presence of the student persists.

SUS has been maturing, it was changing the way to prepare the worker, the institution was changing the way to prepare the academic, but still the user continues to want medical care! (Bibiana - M) 
It is slow, it is laborious, but a little bit you see the result [...] the impression it gives is that we are always going for it, and that this reorientation of training cannot develop at the same pace as the SUS model is developing. (Capitu - M)

The teaching representative realizes that the Pró-Saúde is configured as a device of change, because the approach with the service is more effective than in the past; there have been advances from a social and health promotion point of view.

[...] I believe that today we are living a transition of models in the service. There are those professionals who are more biologists, there are those who have a more social approach to the process. It is a period of change and Pró-Saúde has the function of boosting movements and reflections. (Guiomar - T)

The study participants refer to the curricular matrix as a problem for the implementation of Pró-Saúde projects. On the other hand, they agree that the Program encourages and is boosting the reorientation of curricula and the approximation between courses, by making epidemiological and social issues, for example, transversal in curricula and not more exclusive to each professional category. However, they are still disjointed among themselves and sometimes between $\mathrm{HEI}$ and the service.

[...] each course made its internship separately [...] Pró-Saúde has been boosting us to see that it has not yet taken effect - the professional qualification of these students, the qualification of the people that are in the network [health care], the grids curricula that have been revised, the possibility that, during the training, to be working together, studying together, this needs to be consolidated. (Capitu - M)

If there were no [Pró-Saúde], we would be far behind, we would not have this reality, from the network to the university, to the teaching, this articulation [...] the PPC [Pedagogical Projects of the Courses] would not be articulated and most them today [...]. (Riobaldo - M)

There is an implication of the Program in practice, because the Pró-Saúde makes the concepts and the legislation itself, discussed in the classroom and is perceived in the daily life:

[...] transforming all this conceptual logic into common sense, so that people can operate in their life, understand how it works for a professor, the neighbor, the mother, the family, we do many exercises in that sense. (Heathcliff - T)

\section{Pró-Saúde as a mobilizer of the territory of practice: com- mitment of the subjects}

Despite the challenges, the components of the intersectoral bodies recognize positive changes, both in the training, especially by the approximation between the courses and the transversality of the themes between them; as well as in the demands that involve the management and practice of the proposed actions, through the integration between teaching and the service. They stress the importance of bringing health knowledge and practice closer together and believe that Pró-Saúde mobilizes, engages and reflects. In this way, it makes it possible for professionals to move out of stagnation, to be encouraged to change their concepts, in a movement of Permanent Education, which contributes to the improvement of practice.

Pro-Saúde managed to make this approach, bringing the academic closer to the reality of the SUS, the [Health] Unit, makes the professional feel more instigated to change some concepts. (Riobaldo - M)

The notion of exchange between the worlds of teaching and service, and the possibility of inserting the user in the dialogue, in the context of training:

[...] the professional has access to updates, because as the student is there, it is causing him [professional] to seek information [...] Still, it has the result for the user, when he can bring it to the discussion, they [the other segments] perceive the user as someone with voice and needs [...]. (Mr. Darcy - SC)

From the point of view of the subjects, the directives that guide the Pró-Saúde are configured as a way to be constructed, but that tends to the success:

I believe there is a path being built. We cannot say what is happening is ideal, but with the construction of these projects in partnership we are improving every day from the needs that the service itself has, thus collaborating with the construction of the projects, for the academic training itself and bringing out reality, with regard to the health service. (Anna Karenina - M)

The statements deal with a network movement, anchored in the need to come and go, to move forward and backward, with a view to adjusting the relationships established there:

[...] our relationship with the Department of Health is very interesting and has been built from some hits and some misunderstandings; so that backing is necessary and beneficial sometimes ... But, not in the sense of invalidating what was done, quite the contrary, it is from the mistakes and correctness that we are building the proposal, needs to review to change. (Guiomar - T)

The observation notes confirm the statements, with regard to the correct answers, the mistakes and the confrontations that have been unfolding in this relation between the worlds of teaching and work, as well as the commitment necessary for each one. Asked by the local coordinator of Pró-Saúde about his impression regarding the challenges of the established partnership, the representative of the care segment pronounces, in one of the meetings:

It is necessary to pay more attention to the demands of the service when designing the projects. There must be recognition of the common goals - who has the practice, who has the knowledge? (Observation Note - representative of the care segment)

As a possibility to consolidate the teaching-service integration, the participants propose to the HEI to act from local needs 
and make the returns consistent with the possibility of change in the service, taking due care not to create demands.

[...] they [academics] are coming to do research, but the research ends there and creates the need for who is going to work with that need! [...] it's no use taking you, pointing out the difficulties, the problems that we have and not trying to make an intervention to change and to improve this service and the training itself! (Bibiana - M)

\section{Pró-Saúde: the reality as living bibliographical material}

Pró-Saúde implies the reorientation of the training insofar as it is no longer possible to prepare subjects without thinking about its axes, since the projects contained in it cause the transformation of the experiences in learning and translate the spaces of the living bibliographic material. Ethics itself, as an element of learning, is no longer the ethics of theory, since it translates into the reality of the daily life of services and of living with the people. Pró-Saúde brought to the university demands and there are, in addition, within the scope of training, paradigms that are changing, in line with its axes.

[...] I can no longer think about the reality of SUS without seeing the settings of practice [...] I begin to see theory in practice, in health spaces, and the great role is to transform these experiences into teaching/learning [...] discovering health spaces as a living, written material. Ethics is not the same as any book, any theoretical referential ... Pró-Saúde has brought an avalanche of demands, of dealing with different themes, in different ways. (Heathcliff - T)

This perspective implies recognizing the space of work as a learning space, which needs to be transformed by the pedagogical intentionality of the professor. It is necessary to transform sterile contents into living contents, into "living bibliographic material".

[...] to think of teaching beyond that content that is in the curricular matrix, but how do I pass that content articulating with everyday reality? From the human being who is sitting in my classroom, thinking about the workplace he is in, the family he lives in, what his neighborhood is like [...] the projects propose changing concepts, changing the way and the approximation with reality, are our three challenges, the three guiding axes of Pró-Saúde. (Aurélia - T)

[...] the health student must also be trained for another type of System, so at the same time, if we can get the student to reflect on the needs of the people, the community ... and start organizing, planning the actions, the services in a way linked to these needs, we are training a new professional, who can have more autonomy, who can work as a team, who can understand the principle of integrality and transform that principle into action, service. (Heathcliff - T)

Pró-Saúde: different looks and places in the training process

The verbalizations about Pró-Saúde call for attention as a promoter of the approach of different subjects and their way of thinking and pronouncing the world, in favor of the reorientation of the training. The subjects that integrate the quadrilateral, in the different training scenarios, need not act as experts, either in relation to the SUS, or in relation to pedagogical practices, because this homogenizes the process and education implies heterogeneity. What matters are the different perspectives on the different situations, from the understanding of each subject on the real needs of the community.

[...]in the beginning, even we idealized a lot of people who should be highly qualified to express a deep reflection about what was happening, then we came across different situations, different looks and understood that all these looks are important for the training process. [...] we cannot make projects of reorientation of the training with experts, as much in the pedagogical question, as an expert in SUS, that is to say, it [process of training] gives from the necessities of understanding of each one, from real demands. (Heathcliff - T)

The needs of the service were addressed from the perspective of its convergence with the reality that comes to the fore, contributing to the training. Each of the segments that are represented in the intersectoral instances of Pró-Saúde have their own guidelines, and it is within the scope of multiplicity of views that one can construct the new.

It is clear that we, from the [Health] Department, had some guidelines for the bureau, the [teaching] institution also had some guidelines from the institution. So, within common needs, what could we build again? [...] I see the SUS as a great guiding of this process, but it is not possible to want to orient alone, have to sit down with the educational institutions, have to listen to the users, have to be dialoguing and looking for alternatives, strategies. (Capitu - M)

In this movement of training restructuring, the subjects perceive certain fragility in the professors' understanding on Pró-Saúde, which remain difficult to operate from more active and integrative methodologies of the contents. They signal the importance of permanent updating and that professors need to be touched for change in the direction of pedagogical reorientation.

[...] there is certain fragility in the understanding of many professors regarding what [Pró-Saúde] is ... if we understand that it is never ready, the professor needs to be reviewing the whole year. (Aurélia - T)

\section{DISCUSSION}

For Paulo Freire, awareness requires the subject to move beyond the field of spontaneous apprehension of reality, reaching a critical sphere in which he assumes an epistemological position. This encounter with the real context materializes in the practice (action with reflection) and is based on the commitment to social transformation ${ }^{(6,16)}$. In the case studied, it is clear the need for participation of all actors involved and the feeling of belonging to the process. This involvement is possible considering man, as a social and historical subject, of the practice that is constituted in social relations. He participates in life and intervenes in the world, conditioned by his conscience 
and the historical circumstances that demarcate the territory and its possibilities ${ }^{(6,8,8,16)}$.

The approximation of theory to practice seems to be closely related to change, which makes sense when one understands the improved practice from the theoretical statement, which is necessary for critical reflection, in order to be confused with it (practice) $)^{(9,16)}$. This movement comes to the encounter of health education as a possibility of construction (theoretical knowledge) and a profile of execution (practices), aiming to reorient teaching and work. Such a mechanism makes it possible to review articulated constructions by teaching, to organize reflection and its implications for work ${ }^{(17-18)}$.

In the composition of the possible and current learning settings proposed, it is feasible to understand the culture of the users and the social challenges they face; the understanding of professional systems of care and healing; in addition to the understanding of health care models, ranging from technologies, knowledge, to institutional policies and propositions. The axes of Pró-Saúde, especially axis B, point to this possibility of change. The axis $C$ implies learning through the pedagogical model that results from learning by doing and also becomes perceptible from the statements ${ }^{(3,15)}$.

The adoption of the investigative attitude and experiences that guide the student to the critical-creative thinking are motivating elements of the learning. Entering the world of work early favors practical-reflexive education and the construction of citizens/professionals prepared to respond and question the demands of this world ${ }^{(19)}$. Education, as a practice of liberation, implies the negation of the abstract, disjointed subject of the world. To compromise means to be able to act and reflect (think about action) from reality. These are the necessary conditions to make man subject to practice ${ }^{(16)}$.

These notes also refer to the Permanent Education of health professionals, inserted in the scope of the initiatives of reorientation of training and management in health through the National Policy of Permanent Education in Health ${ }^{(3-5)}$. It mobilizes and strengthens the formal education initiatives and the practices of care, according to SUS guidelines, in search of the commitment of network professionals. In line with its assumptions, the reorientation actions promote the intersection between teaching and work, by calling the University within the SUS and this to imply the training, forming a network that operates in both worlds (work/service and teaching/health education) ${ }^{(18)}$. The movement of approach between the worlds promotes the gradual change of the model of care and training, in line with the principles and guidelines of the SUS, as it contributes to the student, future worker, and professional of the service incorporate the SUS principles into a permanent action, based on autonomous reflections and attitudes. Thus, the action of axis A of Pró-Saúde is evident, which suggests Permanent Education in strategic areas or with shortages of qualified professionals for the SUS, bringing the HEI professional closer. We also perceive the axis $B$ that expresses the integration between teaching and service, allowing the student to act on problems and assume responsibilities, as care provider, according to their degree of autonomy ${ }^{(3-5)}$.
In order to approach and juxtapose the worlds of teaching and service in health, it is necessary to understand them from two distinct cultures and the relations of power that develop and articulate in the social order. They cannot be understood naively, as if they depend only on individuals. Such antagonisms and conflicts need to be assimilated within the work process and social reality ${ }^{(19)}$. With such prerogatives, the axis $\mathrm{C}$ contributes, through the articulation of the classical theory-practice sequence, in the sense of building knowledge based on action-reflection-action ${ }^{(3,8)}$. In this way, Pró-Saúde operates as a mobilizer of a territory of commitment of the subjects, whose essence is the approximation of theory and practice, of the academy with the public health services, as a fundamental device to transform the learning, based on reality Social. However, it must be understood that the municipal network, as a locus of health work, offers numerous learning opportunities for students, but it is also a complex space, whose everyday relationships present problems to be faced. The $\mathrm{HEl}$, as a locus of education, represents an important opportunity to increase the knowledge and professional qualification for the workers; so that there is a kind of necessary symbiosis between these two worlds. At this intersection, the accountability of all partners in the production of health education and care is fundamental, which makes Pró-Saúde mobilize the practice territory and transform the care model.

The questioning conception reinforces change, from the awareness-raising grounded in the consciousness-world relationship and in the critique of the reality posed. As men respond to the challenges of the world, they temporize the geographical spaces, creating history ${ }^{(6,16,18)}$. With this logic, the axis B of PróSaúde presupposes completeness, with preference for action over facts to the detriment of boosting practices that imitate reality, but do not reproduce it in the complex dimension of human comprehension ${ }^{(3)}$.

As a device that fosters teaching through experience, Pró-Saúde is in the process of formulating new ways of teaching, based on the approximation of theory and practice. This requires a re-reading of the world and openness to the transformation of the training process. This "reading of the world" precedes the reading of the word, in search of the comprehension of the text, of the objects in it, transposing generalization, to what is tangible ${ }^{(6,8)}$.

Another proposition of the axis A of Pró-Saúde concerns actions, which need to be adjusted to the loco-regional reality ${ }^{(3-4)}$. It is in this sphere of reasoning that the interviewees draw attention to the possibility of reorienting training to the logic of the SUS, based on an educational process that fosters the protagonism of the student. It should reflect on the reality in which it is immersed and, based on it, plan actions together with the multiprofessional team, transforming the principles of the System (for example, integrality) into concrete actions. Raising awareness presupposes a displacement of reality and, at the same time, it is in reality that the elements that form the consciousness are inserted. Raising awareness, therefore, for Freire ${ }^{(6)}$, is a constant reflection on practice and thus commit to change. Therefore, the importance

1 Pró-Saúde is organized from three structuring axes: A) theoretical orientation, B) practice scenarios and C) pedagogical guidance, each of which has three specific vectors with an "objective image" - a desirable situation ${ }^{(3)}$. 
of teaching how to think, in order to effect the training of the critical-creative professional of the thinking being and, therefore, autonomous citizen. This way of teaching/learning implies the formation of questioning subjects, as they demand to implement actions permeated by elements that boost critical-creative thinking. Thus, the educational process is an exercise of reflection, anchored in the knowledge acquired in the everyday in a formal way (books, school...) and informal (way of living life) ${ }^{(8)}$. These characteristics make Pró-Saúde contributing to the reorientation, insofar as it translates health care spaces into living bibliographical material and also acts on the contrary movement, attributing meaning to the theory.

Development and change are no longer the exclusive tasks of the professor and the health worker, but of a network that operates in the world of work and the world of teaching and which requires different and complementary views from all those involved in the process. In each statement made in the classroom, and in each action performed in the service practice, there is a pedagogical movement that articulates theory and practice that, at the same time, leverages the change towards the consolidation of the SUS.

Within the scope of the proposal to reorient the process of training health professionals, in order to offer the society professionals prepared to respond to the needs of the Brazilian population and to the consolidation of the SUS, Pró-Saúde proposes to establish mechanisms of cooperation between the network managers and educational institutions, providing for the improvement of the quality and the resolubility of the care given to the citizen ${ }^{(3-5)}$.

This new perspective of health education, in several settings (university, health service, community), with different subjects (professors, professionals, users) meets Freire's ideas ${ }^{(6,8,16)}$ when he affirms that one learns in the world, mediated by it, in interaction with reality. If to educate means to be able to intervene in the social space in which man is inserted, this movement can only happen when this man is immersed in its context.

Education is done in heterogeneity, which enriches dialogue and enables the exercise of democracy. It is the social relations that illustrate the beauty of being people, because they allow for respect for different people and involvement in common constructions. Nobody knows more than the other; everyone knows something and learns in cooperation ${ }^{(8)}$. Beyond the importance of content, the critical-epistemological position of students before them, that is, the way they are apprehended and incorporated into their practice, is also important. The dialectical understanding of education implies the art of knowing, in which "professors and students must assume the critical role of cognitive subjects"(20). This requires the professor to reconfigure knowledge and recognize that it is necessary to work in order to transform. He must consider the new paradigms in the teaching action, must recognize that the change operates not only in the intellectual act, but also in individual and collective actions that allow tying new attitudes to face the life. On this point, it is important to emphasize the importance of pedagogical practice in the learning spaces as a privileged locus of construction of the questioning subject, which transcends the need for a theoretical-practical knowledge, including attitudes such as relationships, empathy and constant encouragement to discussions that allow reflect on this ${ }^{(19-20)}$. This practice must be centered in dialogue and based on a dialectical-dialectic relationship between professor and professor, in the perspective of problematizing education. It is added that this is only possible insofar as the professor has humility as a characteristic, is recognized as being unfinished, perceiving the limits of his knowledge and the possibility of learning in the relationship of interaction with the student ${ }^{(8,20)}$.

The actions of Pró-Saúde are based on problematizing education, based on a permanent effort, in which the subjects are perceiving, critically, how they appear in the world. In the proposed way, the professor's knowledge stems from his commitment to the changes and transformations of teaching practices. These should go beyond the act of spreading knowledge, through the mediation of the process, helping the students to increase their possibilities of knowing, questioning and interacting with the world ${ }^{(6,20-21)}$.

These findings reflect two important questions: that learning in the health area is directly influenced by the conditions of the environment in which the practices take place; and that training must respect, in addition to the changes in the work process, the accelerated pace of evolution of knowledge, in view of a balance between technical excellence and social relevance. To train democratic citizens with knowledge, skills and attitudes, to work in a qualified and integrated health system, requires the opportunity to experience the relationships established in this context, recognizing the provocations of the different looks and places in the training of these professionals.

\section{Study limitations}

The study presented some limitations because it deals with the reality of a municipality, which makes it difficult to generalize the findings to other social contexts and precludes the need to carry out other research that explore the theme in order to contemplate other aspects not addressed.

\section{Contributions to the sector of Nursing}

The contributions to the area of nursing reside in its insertion in the scope of public policies of health and education. In this sense, Pró-Saúde contributes to the reorientation of training, by strengthening initiatives of curricular changes with a greater appreciation of student participation; and to change the care model, by recognizing the network as the privileged locus of this construction. However, it should be stressed that change is a slow process and implies individual attitudes and perception of common goals.

\section{FINAL CONSIDERATIONS}

Pró-Saúde encourages professionals to change concepts, in a path of permanent education and democratization, through the exchange of knowledge between the worlds of teaching and service, with the possibility of inserting the user in the dialogue. In this direction, it operates, in the constant movement of coming and going, to advance and retreat, with a view to the adjustment of the relations established there. These possibilities converge in the perspective of Pró-Saúde as a mobilizer of the territory of practice, above all, through the questioning of daily work, in 
$\mathrm{HEI}$ and in the network, since it brings the worlds of education and work closer together, boosting reflection-action-action.

Another issue addressed concerns the translation of health production spaces as living bibliographical material, since PróSaúde recognizes the locus of practice as a locus of learning, in a dynamic anchored in the possibility of reading the world, in which the pedagogical attitude of the professor is highlighted. The demands occasioned moved paradigms that also redefined in the direction of the Program axes. Thus, the various subjects involved are considered, with singular ways of thinking and pronouncing the world, from the understanding of each one on the real needs of the community. These multiple glances allow respect for differences and involvement in constructions that are common to all.

The commitment to change is made possible by the fact that the three axes that guide the proposal are anchored in the educational process, which foresees the approximation of man to the challenges of the world, questioning and practice. The actions of Pró-Saúde intensify in the direction of the integrality, incorporating to the perspective of the student, of the professor and of the worker, the prioritization of the qualified care, from the needs of the community.

\section{REFERENCES}

1. Merhy EE. O ato de governar as tensões constitutivas do agir em saúde como desafio permanente de algumas estratégias gerenciais. Ciênc Saúde Colet[Internet]. 1999[cited 2015 Oct 19];4(2):305-14. Available from: http://www.scielo.br/pdf/csc/v4n2/7114.pdf

2. Campos FE, Haddad AE, Pierantoni CR, Breneelli SL, Cury GC, Morita MC, et al. O Programa Nacional de Reorientação da Formação Profissional em Saúde: Pró Saúde. In: Pierantoni CR, Viana ALA, (Orgs.). Educação e Saúde. São Paulo: Hucitec; 2010.

3. Brasil. Ministério da Saúde. Ministério da Educação. Programa Nacional de Reorientação Profissional em Saúde. Pró-Saúde: objetivos, implementação e desenvolvimento potencial. Brasília, DF; 2007.

4. Brasil. Ministério da Saúde. Ministério da Educação. Educação Permanente em Saúde: um movimento instituinte de novas práticas no Ministério da Saúde: Agenda 2014. Brasília: Ministério da Saúde; 2014.

5. Brasil. Ministério da Saúde. Ministério da Educação. Portaria № 278, de 27 de Fevereiro de 2014. Brasília: Ministério da Saúde, 2014.

6. Freire P. Conscientização: teoria e prática da libertação: uma introdução ao pensamento de Paulo Freire. São Paulo: Centauro; 2001, 116p.

7. Lima MM, Reibnitz KS, Kloh D, Vendruscolo C, Correa AB. Dialogue: network that intertwines the pedagogical relationship into the practical-reflective teaching. Rev Bras Enferm [Internet]. 2016[cited 2016 Nov 19];69(4):610-7. Available from: http://www. scielo.br/pdf/reben/v69n4/en_0034-7167-reben-69-04-0654.pdf

8. Freire P. Pedagogia da autonomia: saberes necessários à prática educativa. 43. ed. São Paulo: Paz e Terra; 2009.

9. Canever BP, Gomes DC, Jesus BH, Spillere LB, Prado ML, Backes VMS. Processo de formação e inserção no mercado de trabalho: uma visão dos egressos de enfermagem. Rev Gaúcha Enferm [Internet]. 2014[cited 2015 Dec 19];35(1):87-93. Available from: http://dx.doi.org/10.1590/1983-1447.2014.01.43279

10. Vendruscolo C, Prado ML, Kleba ME. Teaching-Service integration within the National Professional Health Education Reorientation Program. Ciênc Saúde Colet[Internet]. 2016[cited 2017 Jan 27];21(9):2949-60. Available from: http://www.scielo.br/pdf/csc/v21n9/ en_1413-8123-csc-21-09-2949.pdf

11. Dias HSA, Lima LD, Teixeira M. A trajetória da política nacional de reorientação da formação profissional em saúde no SUS. Ciênc Saúde Colet[Internet]. 2013[cited 2015 Feb 22];18(6):1613-24. Available from: http://www.scielo.br/pdf/csc/v18n6/13.pdf

12. Vendruscolo C, Trindade LL, Krauzer IM, Prado ML. A inserção da universidade no quadrilátero da educação permanente em saúde: relato de experiência. Texto Contexto Enferm [Internet]. 2016 [cited 2015 Feb 22];25(1):1-7. Available from: http://www. scielo.br/pdf/tce/v25n1/0104-0707-tce-25-01-2530013.pdf

13. Yin RK. Estudo de caso: planejamento e métodos. 4. ed. Porto Alegre: Bookman; 2010.

14. Ceccim RB, Feuerwerker LMC. O Quadrilátero da Formação para a Área da Saúde: ensino, gestão, atenção e controle social. Physis[Internet]. 2004[cited 2015 Feb 22];14(1):41-65. Available from: http://www.scielo.br/pdf/physis/v14n1/v14n1a04.pdf

15. Minayo MCS. O desafio do conhecimento: pesquisa qualitativa em saúde. 14ạ ed. São Paulo: Hucitec; 2014.

16. Freire P. Educação e Mudança. 34. ed. Rio de Janeiro: Paz e Terra; 2011.

17. Biscade DGS, Pereira-Santos M, Silva LB. Formação em saúde, extensão universitária e Sistema Único de Saúde-SUS: conexões necessárias entre conhecimento e intervenção centradas na realidade e repercussões no processo formativo. Interface [Internet]. 2014[cited 2015 Dec 20];18(48):177-86. Available from: http://www.scielo.br/pdf/icse/v18n48/1807-5762-icse-18-48-0177.pdf

18. Ceccim RB, Ferla AA. Abertura de um eixo reflexivo para a educação da saúde: o ensino e o trabalho. In: Rego S, (Org.). Educação Médica: gestão, cuidado e avaliação. São Paulo: Hucitec; 2011.

19. Kloh D, Reibnitz KS, Lima MM, Wosny AM, Boehs AE. The principle of integrality of care in the political-pedagogical projects of nursing programs. Rev Latino-Am Enfermagem[Internet]. 2014[cited 2015 Jun 23];22(4):693-700. Available from: http://www. scielo.br/pdf/rlae/v22n4/0104-1169-rlae-0104-1169-3381-2469.pdf 
20. Silva LAA, Soder RM, Schimdt SM, Noal HC, Arboit ÉL, Marco VR. Arquétipos docentes: percepções de discentes de enfermagem. Texto Contexto Enferm[Internet]. 2016[cited 2017 Jan];25(2):1-8. Available from: http://www.scielo.br/pdf/tce/v25n2/0104-0707tce-25-02-0180014.pdf

21. Kempfer SS, Prado ML. Reflecting about assessment by reflective-critical and creative thinking in nursing education in Brazil. J Nurs Care [Internet]. 2014 [cited 2016 Feb 29];3(6):1-2. Available from: http://www.omicsgroup.org/journals/reflecting-aboutassessment-2167-1168-3-e118.pdf 